\title{
FORCED INDUSTRIALIZATION IN ROMANIA AND FOREIGN TRADE CHANGES DURING SOCIALISM
}

\author{
Eugen GHIORGHIŢĂ \\ “Spiru Haret" University, Ion Ghica Street, no. 13, Bucharest, 030045, \\ Romania, Tel.: +40214551000, Fax: +40213143900, \\ Email:eugenghi@gmail.com
}

\begin{abstract}
During the 40 years (1949-1989) of centralized management of the economy, Romania was transformed from an agrarian-industrial country into an industrial-agrarian country, but not beyond the stage of a developing country.

Planning the formation of the accumulation fund and the fixed funds allocation made possible to faster diversify and increase the industrial production.

In a first stage, during the $8^{\text {th }}$ decade (1971-1980), the increase in imports of capital goods needed in industries' technology revamping engendered the growth of Romania's foreign debt.

In the $9^{\text {th }}$ decade, the policy of forced payment of previously accumulated foreign debt was achieved by aggressive compression of imports and boost of exports.

At the end, in 1989, Romania's foreign trade structure corresponded almost completely to the structure of the supply from the countries producing industrial processed goods. From this point of view, Romania became, after four decades of accelerated development, an acceptable client to Western exporters.
\end{abstract}

Keywords: economic growth; industrialization; development dictatorship.

JEL Classification: B25, O10, O43, Q56, Z13

\section{Introduction}


Issue 4/2015

The increased pressure entailed by the payment of the external debt as well as the agrarian-industrial character of the Romanian economy until 1940 led to the adoption of the accelerated industrialization solution.

The need to adopt a consistent policy of industrialization was already consecrated by the overwhelming majority of economic works in the interwar period, as industrialization was considered the only effective way of achieving the macroeconomic balance.

The experience of the 80 years of (1859-1939) transition to capitalism had highlighted serious inadequacies of the economic systems of the 'lagging behind' countries slow pace of economic growth, internal inequalities in regional development, ever more pronounced social segregation, dependence of the capacity to pay the country's foreign debt on the instability of the agricultural production respectively on the exports of raw materials and semiproducts, maintaining a relatively small internal urban market, the agricultural relative overpopulation, lack of qualified personnel for non-agricultural sectors, maintaining a high level of illiteracy, etc.

Countries at the beginning of industrialization could hope for an intensive development, partially recovering the gaps towards industrialized countries only by accelerating industrial development. It was relatively easy to justify and support such an imperative, but almost impossible to achieve it within the capitalist system already applied for 80 years.

Forecasting calculations were daunting about the possibilities of interwar Romania. The most delicate problem was the chronic shortage of funds, the scarcity of capital for public and private investment. Foreign capital invested in Romania contributed sequentially in several sectors only, and as duration in the short and medium term to the development of economic sectors.

Government budget revenues would not have been able even in the most optimistic estimates to cope extensive investment programs. One example is illustrative: developing national energy system (not to mention upgrading the infrastructure or mechanization of the agriculture).

Until 1940, the Romanian capital private initiative remained relatively dominant at the small and medium enterprises level. For "peak" sectors at the time (mining, oil refining, wood) foreign capital was 
prevailing which, as we were saying, could have only a limited and temporary positive influence for overall economic growth of the country.

The industrialization of the country would become the axis of socialist economic policy. Domestic capital accumulation and planned investments distribution on sectors of the economy were to ensure high growth rates, specific to a forced, accelerated development, impossible to achieve within the conditions of the market economy known until 1940.

The international institutional framework - solving the problem of the external market to accelerate the development of socialist economies

Dating back to the sixteenth century, the debate of ideas on ways to ensure the economic growth of a country focuses more strongly, since the second half of the nineteenth century, on the importance of foreign trade.

Foreign market expansion in terms of the classical theory of international trade (Smith-Ricardo-Mill) would not have to be a significant problem, as each country could participate in the international values exchange "with what had been destined".

Thus, if a country could naturally produce satisfactory amounts in cereals, bananas, coffee, saltpetre, oil or diamonds, for example, according to the principles of free trade, that country only had to change its products for those of other countries ensuring the demand for those goods that could not be naturally achieved from salt, pepper, oranges, glass, mirrors, nails and rails to machinery, drilling rigs and refinery and, nowadays, computers.

Thus, the international trade of goods and services produced in compliance with the international labour division and free trade principles should vouch to all participants' advantages and benefits, enshrining peace and universal harmony.

The period of new great powers industrialization, such as Germany and the US, led to a reassessment of the international trade theory and, especially, to questioning the effectiveness of the application of generalized free trade. It developed so with increasing virulence, especially after 1880 , the re-escalation of mercantilist practices from the dawn of capitalism, now called protectionism. 
Issue 4/2015

The most serious curtailment of confidence in the "healthy" character of free trade principles brought by the protectionist theory targeted the very foundation of these principles: within the international trade were not exchanged goods based on equivalence according to the prices of goods and services, but exchanges of non-equivalence given by disparities between the levels of productivity of production factors (natural factor: the soil, human: the labour, social-economic: the capital).

The expansion of the European market after 1850 brought with it a worsening issue: the acknowledgement of economic disparities between countries and their aggravation. The limits of expansion of the developed Europe economy revealed with increasing obviousness.

By 1914, however, the general operation of the two fundamental systems (the gold standard monetary system and the multilateral trade) assured an overall development of the European economy, even though the widening gaps continued to become chronic.

Following the serious distortions of the international economic relations during the 1930-1940 period, became clear the need for a radical restructuring of the international trade regime, as well as the imperative of accelerating growth in the areas designed for the developed economies expansion.

Increasingly striking warning signals began to be heard highlighting a serious threat to the continued economic growth of developed countries: through the further aggravation of economic disparities, the competitive advantage held by these countries resulting from the international division of labour risked to be left without the appropriate markets, clearly leading to the decline of large or small industrialized states.

In order to regulate international economic relations after 1944, in addition to the reorganization of the League of Nations under its new name of United Nations Organization (UNO), a number of new institutions was established such as the International Monetary Fund (IMF), the World Bank, the International Bank for Reconstruction and Development (IBRD), the General Agreement on Tariffs and Trade (GATT), the United Nations Conference on Trade and Development (UNCTAD), etc. 

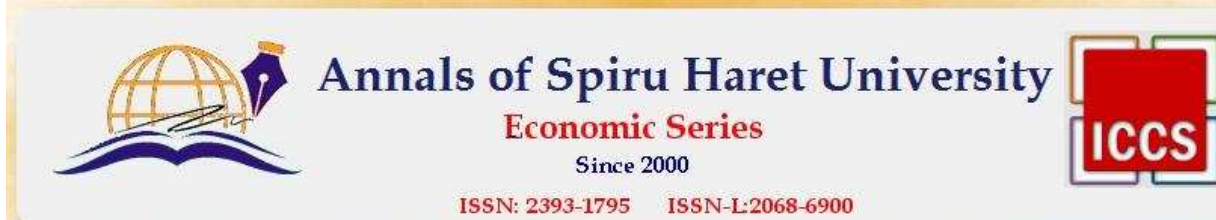

Issue 4/2015

The chances of the countries at the beginning of their industrialization to compete with industrial competitive products in the international market along with the increasingly progress due to faster technological change in developed countries were virtually nil.

For the new bloc of socialist countries shaped after 1945, the solution to the foreign market issue was the establishment of the Council for Mutual Economic Assistance (CMEA) in 1949.

Among other functions (planning correlation, foreign exchange, financial assistance, etc.), the CMEA market was meant to ensure the supply of raw materials and the sale of industrial and agricultural products of each member country on more favourable terms than those offered by the Western markets.

\section{The purpose of the industrialization policy}

The stated objective of socialism was the country's transformation from agrarian-industrial to industrial-agrarian. Romania was to develop "multilaterally" to acquire a structure of sectors and a quantitative and qualitative level comparable to those of developed countries.

For countries with a low level of industrial development, the prevalent development of heavy industry was considered the unique and secure way to ensure a rapid and seemingly sustainable development of economies as a whole. Moreover, the Soviet experience itself (1927-1945) represented a confirmation of the expected success in other developing countries.

\section{Historical prerequisites of Romania's industrialization}

During the eight decades of capitalism establishing (1859-1939), the Romanian economy was gradually drawn into the circuit of Western values. In this new context Romania had to start its modernization process.

The modernization of the Romanian society required public borrowing which brought about the foreign debt increase. In order to pay the foreign debt tontines, Romania had to secure the necessary foreign currency liquidity. But the Romanian economy depended largely, especially until the early twentieth century, on its agricultural output. Romania's export 


\section{Issue 4/2015}

capacity and therefore the ability to import were determined by the annual level of agricultural production.

The seasonal nature of agriculture and the influence of the climate engendered the instability of the agricultural production. Therefore, the fluctuations in agricultural output caused serious imbalances both domestically and in the international economic relations. Depending on agriculture, Romania's international payment capacity was uncertain, affecting the financial potential to support imports.

Industrialization was supposed to attract a large part of the labour force surplus in rural areas, while the phenomenon of relative agricultural overpopulation had become a serious demographical and economic problem during the interwar period.

In academia, in the press, as well as among politicians and even in the business environment the necessity of developing a powerful industry had become a dominant idea until 1940. Moreover, under the dictatorship of development, the accelerated and forced industrialization of Romania has become the main focus of the leadership of socialist Romania.

\section{The industrialization strategy during socialism}

The policy of industrialization meant developing with priority the heavy industry producing investment goods (capital goods) or "means of production", as they used to say at that time.

The idea of the priority development of these sectors was neither by the Bolsheviks nor by the communists inspired. The economic literature had already shaped a school of thought which argued the meaning of this strategy: developing the national productive forces [List, 1841] could be complete and real only by developing mainly the sectors with a labour productivity above the national average [Manoilescu, 1929].

Particularly encouraging for LDCs industrialization imperative argument, were also the findings of the League of Nations study Industrialisation et commerce extérieur published in 1945. The solution 
suggested by the authors of the study targeted the financial sources for industrial investments in national accumulation. ${ }^{1}$

The historical experience of the previous 80 years of establishing capitalism in Romania had shown that domestic capital accumulation was extremely low compared with the needs of economic and social modernization. On the other hand, it was estimated that autonomous foreign capital investments in industries of the countries at the beginning of their industrialization will not be sufficient to cover the necessary.

Therefore, one of the functions of the socialist government was to force the domestic capital accumulation. On that effect, the planned distribution of the national income as accumulation fund and consumption fund was the way of achieving the necessary investment funds. The trend of the single (communist) party policy aimed at achieving a certain balance between the two funds.

Planning extremely high growth rhythms resulted in high rates scheduled for the accumulation fund to the detriment of consumption. Basically, within the framework of the development dictatorship, the totalitarian leadership aimed at raising increasingly larger investment funds (during 1961-1980) from a five-year plan to another, by restricting the household consumption.

The industrialization policy adopted in socialism has followed from the beginning the intensive development of heavy industry (the Group " $\mathrm{A}$ " sectors, producing capital goods) i.e. the extractive, metallurgical, chemical, electrical industries, etc. and especially the machine and equipment industry. Machine and equipment industry was considered the "backbone" of the national economy: on its development depended the real economic independence of the country.

The funds allocated to Group "B", respectively to sectors of industry producing consumer goods (food, textile, footwear, etc.) were significantly lower than those allocated to Group "A".

1 See Industrialisation et commerce extérieur, Société des Nations, Genève, 1945. 
Issue 4/2015

Increasingly more pronounced in the 80 s were felt the Romanian economy autarky attempts, focusing on severe curtailment of imports, relying on domestic industry's production capacity, which was not really stimulated.

Despite the controversies related to the usefulness, purpose and effectiveness of industrialization, it is obvious that after 40 years of forced development, in 1989 Romania's economic structure was significantly changed: the industry became the main sector.

\section{The relation between industrialization and foreign trade}

The transition to socialism, in general, and in the countries of Southeastern Europe in particular was done forcibly, through the intervention of Soviet troops. For a number of countries, socialism was considered the most effective solution to accelerate the development and growth in as short as possible historical times. Imposing "the good" by force was achieved by the "dictatorships of development" under socialism.

Forced development, labelled as socialism, was largely the continuation of civilizing by force - the force of the market - under the label of modernization and capitalism, which began in Romania with the reign of Alexandru Ioan Cuza.

The association of the industry evolution with that of foreign trade is not accidental. Until the First World War and then until 1940 all been written and talking about the difficulty, not to say "impossibility", to develop industry in Romania, namely generally in little or no industrialized countries, first due to the limited internal and external market.

The domestic market problem would be solved by socialism through urbanization and increasing rural demand for industrial products. The limits of foreign market remained a challenge to identify the outlets inherent in the forced industrialization of the socialist countries. The industrialisation required external transactions growth, not only for raw materials supply but especially for exports of processed (manufactured) products.

It was easy to imagine that Romanian industry products and, generally, of the industry of most socialist countries in different stages of the early industrialization would not have faced competition in Western 
markets. To be "competitive" in the foreign market, the socialist countries needed an own market, relatively isolated from competition specific to large industrial producers.

The solution adopted was the creation of the Council for Mutual Economic Assistance (CMEA) in 1949. 1989

Synthetic indicators of the industry evolution between 1950 and

The industry's development and modernization is reflected by the summarized evolution of the number of enterprises, labour input and the dynamics of synthesis indicators.

The share of financial resources for achieving industrial investment respectively the share of accumulation fund in national income were greater than those destined to other sectors. The intense focus on industry development materialized in the increase in number of the industrial units.

The number of industrial enterprises increased from year to year, from 1658 in 1950 to 2102 in 1989, the republican subordinated being net "favourite" to local subordinated ones. It should be well understood that the number of enterprises is not an eloquent indicator by itself. What mattered in the first place was the size of the enterprise; the republican subordinated had a much larger size.

The investment effort inherent in the establishment of such industrial "mastodons" was exceptional. The evolution of locally subordinated enterprises was tortuous, reflecting the diminishing interest in local industry development.

It was thus confirmed the need for priority development of large industrial enterprises stipulated by Mihail Manoilescu, Ştefan Zeletin and others, thus being virtually diminished the importance of National Peasants' Party's vision about the development of industries connected to agriculture, located mainly in rural areas.

The structure of employment has radically changed in 1989 compared to 1938 and 1950. In 1930 the share of employment in industry was $7.7 \%$ of total employed population, while the urban population share was $21.4 \%$. 

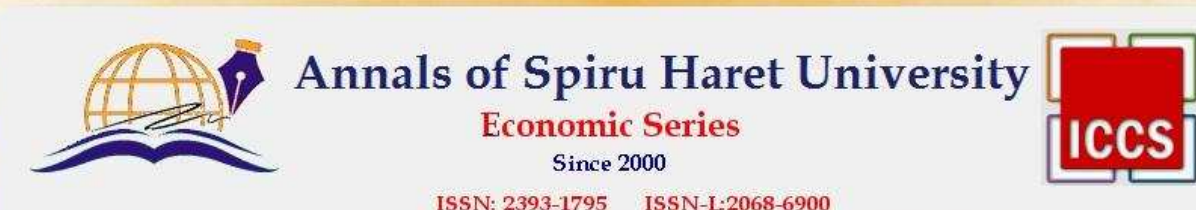

Issue 4/2015

Romania's transformation from an agrarian-industrial country into an industrial-agrarian country is reflected, among other indicators, by the ratio change of industry and agriculture employment shares. ${ }^{2}$ In this respect, the period 1970-1980 was decisive: the share of employment in agriculture decreased from $49.1 \%$ to $29.4 \%$, while the share of employment in industry increased from $23 \%$ to $35.5 \%$.

Consequently, compared to the beginning of the period (1950), in 1989 the demographic indicators structures distributed by urban-rural areas and labour distributed by sectors were radically altered. The population employed in industry increased more than fourfold, from 1 million in 1950 to 4.1 million in 1989; the share of employment in industry increased from $11.9 \%$ to $38.1 \%$ of total employed in the economy, while the share of employment in agriculture declined from $74.1 \%$ to $27.5 \%$.

Forced industrialization also engaged the accelerated urbanization process. In 1989 the urban population had a share of $53.2 \%$ of the total population, having increased from about 3 million in 1938 to 5.5 million in 1956, namely more than 11 million inhabitants in 1989, i.e. almost four times compared to 1938 .

\section{Industry's contribution to the formation of Social Product and National Income}

The increased importance of the industry in the national economy is reflected first by the contribution of this sector to the formation of social product (SP) and national income (NI).

Industry's contribution to the formation of Social Product increased from $39 \%$ in 1938 to over two-thirds in 1989, while the share of industry in National Income rose from $30.8 \%$ to only $58.1 \%$. The differences between the weights of the two indicators, for example in the years 1938, 1960 and 1989 , were caused by sharper increase in material costs. Thus, the share of expenditures made in industry in total material costs rose over the same period from $36.6 \%$ to $71 \%$.

${ }^{2}$ Romanian Statistical Yearbook, 1990, p. 51; A. Bondrea, Starea naţiunii 2000. România încotro?, Editura Fundaţiei România de Mâine, Bucureşti, 2000, p. 195.

18 

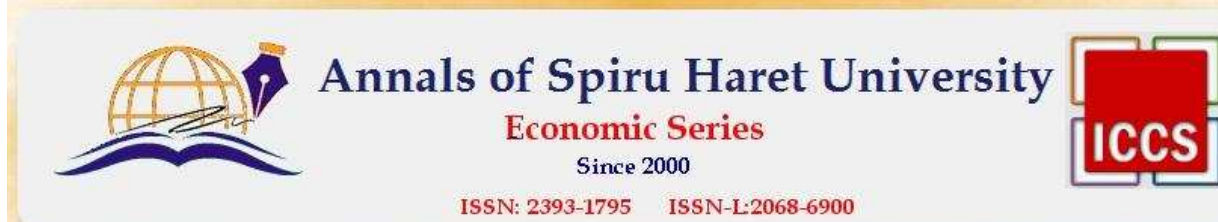

Issue 4/2015

The investment effort devoted to industrial development was remarkable. The investment in the industry held the largest share of total investment in the economy, i.e. between $43 \%$ and $50 \%$ (maximum reached in 1986), increasing from about 2.4 billion in 1950 to over 124 billion lei in 1986.

Increased investment brought about the industrial production growth which recorded the maximum increase (calculated in comparable prices) of 44 times in 1989, compared with an investment increase (calculated at current prices) of only 37.2 times versus base year 1950 .

The apparent increase in investment efficiency can be inferred from the comparison with the investment dynamics of industrial production compared to 1980 as a year of reporting. While investments diminished from $93 \%$ in 1985 to $83 \%$ in 1989 , industrial production increased from $120 \%$ to 133\%, showing a slight decrease in 1989 compared to 1988. The industrial production growth however was not the result of net investments, but of the average longer operating period of fixed assets in previous periods.

The efficiency of fixed assets in the industry, after a real growth recorded during 1970-1980, diminished in the last decade. National income realized in the industry related to the value of fixed assets in the industry fell on average annually by 3.4\% during 1981-1985 and 8.5\% during 19861989. [Constantinescu, 2000]

Factors leading to reduced efficiency of fixed assets were: the overendowment with fixed assets of enterprises; long-term effects of the energy and raw materials world-crisis (1973-1979) which led to early degradation of imported technologies; reducing domestic and external demand for some industrial products (tractors, agricultural machinery, energy and oil equipment, lathes, etc.); imbalances within enterprises through retrofitting gaps between sections; breakdowns and faults caused by the lack of spare parts or the incomplete providing of fixed assets servicing mainly after imports restricting during 1982-1989.

Dispersal of investment destination in the last decade of socialism has generated unsustainable programs and planning of production and labour. These causes have led to run time extending and delaying to operate the objectives by 2-5 years and more. 
Issue 4/2015

The evolution of output and investments by industrial sectors between 1950 and 1989

The structure of industry sectors has changed, focusing on the development of heavy industry sectors (Group A). Group A share in total industrial production increased from $45.5 \%$ in 1938 to $52 \%$ in 1950 and $72.5 \%$ in 1989 with a corresponding reduction of the Group B share (consumer goods). ${ }^{3}$

For the Group A the highest increases in the share of production volume were recorded by the following sectors: the share of industry engineering and metal processing increased from $10.2 \%$ in 1938 to $13.3 \%$ in 1950 and $27.7 \%$ in 1989 ; similarly the share of chemical industry production went from $2.7 \%$ to $3.1 \%$ and $9.8 \%$, while non-ferrous and ferrous metallurgy increased from $6.7 \%$ to $7.5 \%$ and $9,8 \%$ respectively.

Group B sectors producing consumer goods marked shares decreases, even if their production has increased in the period under review. The share of food industry production decreased from $32.4 \%$ in 1938 to $24.2 \%$ in 1950 and $11.6 \%$ in 1989 . For textile industry, the evolution of its share in total industrial production was upwards, from $9.4 \%$ in 1938 to $11.1 \%$ in 1950 and declining to $6.6 \%$ in 1989.

Increasing production of the different sectors followed the same array of development with emphasis on heavy industry.

The most significant increases in production were recorded by the chemical industry - 221 times, and machine building - 158 times, far above the industry average as a whole, while light industries increases were below the average of industry's total respectively 24 times for the textile industry and only 11 times for the food industry.

In the period 1950-1989 the average annual growth of industrial output as a whole was $10.2 \%$, being surpassed by Group A (11.1\%) represented by the Chemical industry (14.9\%) and Non-metallic minerals extraction and abrasive products industry (14.7\%), Engineering and metalworking (13.9\%), Coke-chemical (12.8\%), Electricity and Building materials (11.2\%).

\footnotetext{
${ }^{3}$ Romanian Statistical Yearbook, 1990, p. 452-455.
} 
Table no. 1. Industrial production dynamics of some main branches between 1950-1989

\begin{tabular}{|l|r|r|r|r|r|}
\hline & $\mathbf{1 9 5 0}$ & $\mathbf{1 9 6 0}$ & $\mathbf{1 9 7 0}$ & $\mathbf{1 9 8 0}$ & $\mathbf{1 9 8 9}$ \\
\hline Industry, total, of which & 100 & 340 & 1100 & 3300 & 4400 \\
\hline Chemical industry & 100 & 658 & 5400 & 17800 & 22100 \\
\hline Machines engineering & 100 & 585 & 2700 & 11000 & 15800 \\
\hline Building materials & 100 & 409 & 1600 & 4700 & 6200 \\
\hline Wood processing & 100 & 317 & 986 & 2000 & 2600 \\
\hline Food & 100 & 238 & 489 & 939 & 1100 \\
\hline Textile & 100 & 235 & 655 & 1900 & 2400 \\
\hline Apparel & 100 & 241 & 736 & 2400 & 4100 \\
\hline
\end{tabular}

Source: Romanian Statistical Yearbook, 1990, p. 432-433.

The main beneficiaries of intensifying investments were oil processing industry, electricity and thermal energy, metallurgy and chemical industries in which there were invested between 48\%-75\%. [Constantinescu, 2000]

The investment effort has not been evenly distributed over the 45 years. Completion of industrial investments and fixed assets operating required different periods of time by the industry in question. Therefore stepping up investment process is best reflected by the investment dynamics outmatching by fixed assets dynamics index - 1.16 in the period 1966-1975, namely 1.32 between 1976 and 1980 .

Between 1980 and 1989 statistical data on production and investments in the industrial sector reflect contradictory developments of the two indicators.

Overall, with a few exceptions (the garment industry, for example), the last decade of the reviewed period investment growth was below the level reached in 1980, while the industries output was considerably higher than in 1980 (Machinery industry and Metal processing, Chemical, etc.).

The explanation for increased production, while reducing investment growth to 1980, is the time gap between the period of maximum investment 

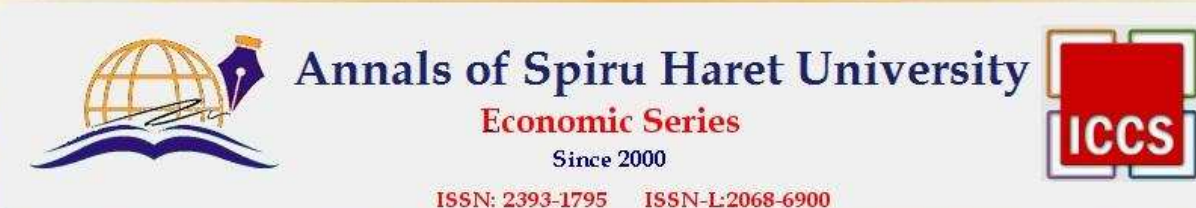

Issue 4/2015

efforts and the lag to operate the respective fixed assets. In the case of highly productive sectors (most industries in Group A), increased investment was made approximately between 1960 and 1980. In a limited number of sectors, investment effort continued after 1980.

With a diversified structure, providing the bulk of the domestic demand of consumer goods and, in the 9th decade, most demand of capital goods, despite halting the refurbishment and despite the extension of the useful life of fixed assets, the Romanian economy was far from being "a pile of scrap".

The lucid observation of maintaining and worsening the gap from the front-developed and even some developing countries must be supplemented by a clear understanding of the realistic possibilities of a forced-accelerated, artificial development. The industrialization of Romania had achieved its historic goal: the compatibility of the domestic demand for consumer goods with the developed countries supply structure.

Reducing the volume of investments in the decade 1980-1989 was caused both by restricting imports and the sustained effort to pay the foreign debt, as one of the major sources to cover investments in the economy in general, and in particular in the industry, was consisting of external loans by the International Monetary Fund (IMF) and the International Bank for Reconstruction and Development (IBRD).

The foreign debt of Romania between 1976 and 1989

Insufficient domestic financial resources for investment were one of the defining characteristics of the economic evolution of Romania between 1859 and 1939. The appeal to foreign capital had become more insistent during conservative governments (1888-1900), respectively during the National Peasants' Party ruling between 1929 and 1933.

The domestic capital accumulation achieved through the autarkical policy applied by socialism, as well as the cooperation relations within the Council for Mutual Economic Assistance (CMEA) should have been sufficient for providing growth resources. But the development acceleration efforts after 1965 proved these were not sufficient. 


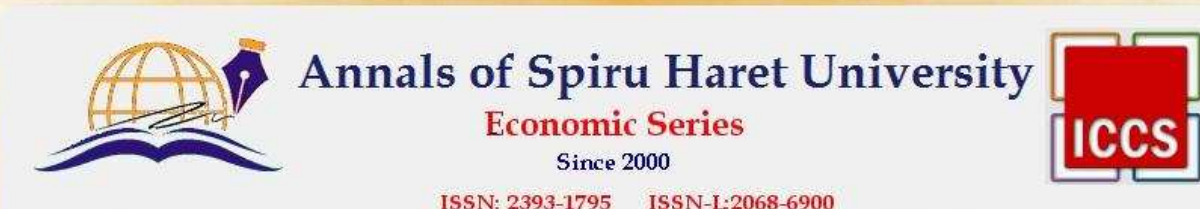

Issue 4/2015

Promoted openness to the West after 1965 and especially after 1968 brought Romania within the International Monetary Fund since 1972.

Table no. 2. The foreign debt of Romania during 1976-1981 - Million US dollars -

\begin{tabular}{|l|l|l|l|l|l|l|}
\hline & $\mathbf{1 9 7 6}$ & $\mathbf{1 9 7 7}$ & $\mathbf{1 9 7 8}$ & $\mathbf{1 9 7 9}$ & $\mathbf{1 9 8 0}$ & $\mathbf{1 9 8 1}$ \\
\hline Romania's foreign debt & 2876 & 3684 & 5170 & 7342 & 9810 & 10546 \\
\hline
\end{tabular}

Source: N.N. Constantinescu, Istoria economică a României, vol. II, Editura Economică, 2000, p. 376.

In, we could say, a necessary way, given the highly accelerated growth planned for the period 1976-1985, Romania began to make increasingly more consistent loans abroad to cover the imports of technologies, machines, equipment, and machinery from the industrialized countries. Foreign currency commercial loans designed to support these imports came from various banks, as well as from the International Bank for Reconstruction and Development (IBRD). In 1976 the foreign debt consisted of \$ 864 million from banks and \$ 2.012 billion from international financial institutions. In just six years the total debt reached $\$ 10.546$ billion, of which 10.160 billion in convertible currencies, marking an increase of 3.6 times.

Most of the external debt consisted of medium and long-term loans for development or modernization to provide the industry with advanced technology and equipment. Medium and long-term debt increased 3.2 times, from 2.4 billion in 1976 to $\$ 7.7$ billion in 1981. Current revenues coming in mostly from exports could not cope with increasing debt pressure incurred particularly in the period $1978-1981$, so in 1981 the arrears had reached \$ 1.1 billion.

Therefore, at the beginning of the 9th decade Romania was facing a real foreign debt crisis occurred only eight years after becoming an IMF member.

Romanian state foreign debt crisis was caused, in addition to massive imports of capital goods, by the following factors: 


\section{Issue 4/2015}

a. Changing of oil and raw materials market conjuncture by oil crisis outset (1973-1979), which created an exceptionally heavy burden by increasing the prices of these products (the oil bill).

b. Higher oil prices added the increasingly higher crude oil imports, inherent in the 8th decade of accelerated development, which had reached $45 \%$ of the total Romanian imports in convertible currencies.

c. In addition to collecting medium and long-term debt, an aggravating role was played by the increased short-term foreign loans, which share in total external debt went from 4\% in 1976 to $22 \%$ in 1980.

d. Western banks have tightened credit conditions for socialist countries following the collapse of Poland.

In order to solve the foreign debt crisis, Romania has turned to the IMF support, which was conditioned by the achievement of an adjustment program to ensure the necessary currency liquidity and rescheduling loans from foreign banks.

Following the implementation of the adjustment program, since 1982 the current account recorded surpluses:

Table no. 3. Evolution of the current account balance of Romania 1981-1989

- Million dollars -

\begin{tabular}{|l|l|l|l|l|l|l|l|l|l|}
\hline & $\mathbf{1 9 8 1}$ & $\mathbf{1 9 8 2}$ & $\mathbf{1 9 8 3}$ & $\mathbf{1 9 8 4}$ & $\mathbf{1 9 8 5}$ & $\mathbf{1 9 8 6}$ & $\mathbf{1 9 8 7}$ & $\mathbf{1 9 8 8}$ & $\mathbf{1 9 8 9}$ \\
\hline Foreign trade balance & 103 & 1814 & 1869 & 2312 & 1772 & 1680 & 2178 & 3750 & 2050 \\
\hline Current account balance & -833 & 1040 & 1160 & 1719 & 1381 & 1395 & 2043 & 3922 & 2514 \\
\hline
\end{tabular}

Source: N.N. Constantinescu, Istoria economică a României, vol. II, Editura Economică, 2000, p. 377.

It is remarkable that after six years (1982-1987) of foreign trade balance surpluses that ensured a current account positive balance, in 1988 and 1989 the current account surpluses exceeded net exports (by $\$ 172$ million in 1988, and \$ 464 million respectively in 1989)!

Before unfolding the process of forced payment of foreign debt, after rescheduling the public debt, the external debt service was the following: 
Issue 4/2015

Table no. 4. Rescheduling and repayment of external debt during 1986-1989

- Million dollars -

\begin{tabular}{|l|l|l|l|l|l|l|l|}
\hline & $\mathbf{1 9 8 6}$ & $\mathbf{1 9 8 7}$ & $\mathbf{1 9 8 8}$ & $\mathbf{1 9 8 9}$ & $\mathbf{1 9 9 0}$ & după 1990 & Total \\
\hline Foreign debt rescheduled & $\left.\mathbf{6 3 9 5}^{*}\right)$ & 5013 & 3456 & 2386 & 1710 & - & - \\
\hline Rescheduled reimbursements & - & 1382 & 1557 & 1070 & 676 & 1709 & $\mathbf{6 3 9 4}$ \\
\hline Effective reimbursements & - & 356 & 4252 & 1790 & - & - & $\mathbf{6 3 9 8}$ \\
\hline Effective external debt at 31 December & $\mathbf{6 9 1 2}^{* *}$ & 6556 & 2304 & 514 & - & - & - \\
\hline
\end{tabular}

Sources: (1) NBR Annual Report, 1998, Statistical Section, Table 17, p. 57* .

(2) N.N. Constantinescu, op. cit., p. 378-379.

Notes:

*) Rescheduled foreign debt was calculated using data from source (2) from the opening balance of $\$ 6.395$ billion and then successively decreasing the reimbursed rescheduled amounts in the second row. Rescheduled foreign debt (6.395 billion dollars) differs from the actual of 6.912 billion dollars, according to NBR updates "considering rescheduling and some loans renewal".

${ }^{* * *}$ According to the source (1), p. $8^{*}$ of the Statistics Section of the same 1998 NBR Report, the external debt published series in the period 1986 to 1989 is different from the one published in the same report at p. $57^{*}$ :

\begin{tabular}{|l|l|l|l|}
\hline $\mathbf{9 8 6}$ & $\mathbf{9 8 7}$ & $\mathbf{9 8 8}$ & $\mathbf{9 8 9}$ \\
\hline 875 & 272 & 106 & 74 \\
\hline
\end{tabular}

Officially, on March 31, 1989 was declared the conclusion of Romania's foreign debt repayment. As evident from the table, the maximum repayment effort was in 1988 and 1989 when they were paid more than \$ 6 billion. The ambition to fully pay the external debt was interpreted as a "foolish megalomania" and as "foolish pride" generally attributed to Nicolae Ceauşescu.

The currency liquidity hoarding effort intended for the payment of Romania's foreign debt had dramatic effects for the national economy:

- Imports of raw materials, technologies, equipment, machinery and cars were severely restricted, being affected the continued economic growth in most sectors of national economy; 
Issue 4/2015

- Exports were boosted by aggressively restricting the investment fund and domestic consumption;

- Diminished domestic consumption affected the material living conditions of the population:

- limiting food and non-food goods consumption in what was left of the domestic output following the exports;

- excessively reducing consumption for a wide range of imported products;

- rationalization of utilities (supply of electricity, heat, water, etc.).

Forcing the foreign debt liquidation in the same period when there were engaged large unproductive investments (People's House) or with a long period of investments return (Danube-Black Sea Canal) led to serious decrease and even stagnation of economic growth committed in previous decades.

The investment effort and forcing the foreign debt liquidation seriously affected the livelihood of millions of citizens.

On the other hand, one can say that the performance of achieving Romania's financial independence in such a short period was remarkable, perhaps unique in history. The overwhelming majority of experts have stated categorically that the so-called "achievement" was a "negative performance", with catastrophic consequences for ensuring the continuation of the upward trend of economic growth. However, on 31 December 1989 Romania had \$ 1.8 billion foreign exchange availabilities and had to receive loans from developing countries amounted to US \$ 2.9 billion. [Constantinescu, 2000]

The evolution of the Romanian economy after 1990 was to confirm or deny the gratuity or the uselessness of the extraordinary effort to which were subjected the inhabitants of the country during the last decade of socialism.

Evolution of the Romania's foreign trade between 1950 and 1989 Dynamics of Romania's foreign trade

The industrialization of the Romanian economy brought about significant increases in foreign trade.

Taking as a basis the year 1950, when net imports (trade deficit) reached 187 million currency-lei, until 1980 the exports dynamics was 

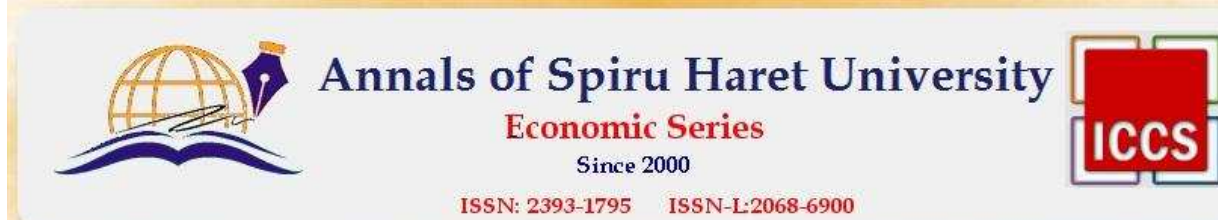

Issue 4/2015

approximately equal to that of imports - 40 times growth. In 1989 exports increased 42 times, while imports only 29 times compared to 1950.

The trade balance was mainly negative between 1950 and 1980. The trade deficit accumulated in each of the past three decades passed from 1.7 billion currency-lei in the period 1950-1959, to 4.5 billion currency-lei in the decade 1960-1969 and to 18 billion currency-lei between 1970 and 1980 .

The currency-leu had no material existence. It was just a monetary unit of account used in the trade with western countries. The name comes from the procedure applied to transform in lei the value of goods denominated in other freely convertible currencies based on the definition (parity) of those currencies into gold.

According to the 1954 Law, a lion was defined by an amount of $148.112 \mathrm{mg}$ gold. The dollar was defined by the Law of 1934 at the parity of $888.671 \mathrm{mg}$ gold. The ratio between the two amounts of gold determined an official exchange rate of 6 lei per dollar. With the crisis of the US dollar, after 1971, the official exchange rate of leu has appreciated against the dollar, after 1980 following the currency market quotations.

For non-commercial relations (tourist trips, for example) were used exchange rates with premium which evolved from $100 \%$ in 1957, i.e. one US dollar was exchanged for 12 lei, until the completion of $200 \%$ premium in 1968, which meant that one dollar was equal to 18 lei. [Kiriţescu, 1997]

Forcing the external debt payment was materialized into external trade surpluses, of about 300 billion lei in the period 1980-1989, large enough to ensure the necessary currency liquidity. and 1989

The evolution of Romania's export and import between 1950

Before the end of World War II Romania's foreign trade was dominated by exports of agricultural commodities and oil respectively imports of finished and semi-finished products.

Romania's forced industrialization policy applied during the period between 1950 and 1989 is reflected by the change in foreign trade structure. 
Issue 4/2015

Export and import structure analysis is based on products grouping according two criteria: provenance of traded goods on the sector of origin (agricultural or industrial) and the degree of products' processing (stage of manufacture: basic-raw, semi-processed or manufactured respectively).

The structure of exports has radically changed over the period analyzed. At the beginning, the agricultural products accounted for 55-60\%, while the industrial goods (including raw materials supplied by extractive industries) $45-50 \%$ of total exports. After 1980, the industrial products had reached a share of $75-80 \%$, while agricultural products $20-25 \%$.

At the beginning of the $6^{\text {th }}$ decade, the unprocessed, basic, and intermediate goods (with a low processing degree) accounted for about $70 \%$ of exports, finished products accounting for only $30 \%$. In the $9^{\text {th }}$ decade manufacturing goods considerably diversified had reached $65-70 \%$ of total exports, as the share of raw materials decreased to only $30-35 \%$.

The literature often mentions that most Romanian products with varying processing degrees were not competitive on foreign markets, as reflected in the prices at which these products were traded.

This lack of competitiveness fully corresponds to the League of Nations forecast study, Industrialisation et commerce extérieur, 1945: developed industrialized countries will always keep a technological advantage to countries undergoing industrialization. In other words, the risk of an industrial real competition from countries like Romania, Poland or Yugoslavia was planned since 1945 as insignificant.

"The competition from the newly industrialized countries can lead to losses in the market of a particular item; but normally these losses tend to be offset by gains from the new application that creates, in different ways, the competition in question." 4

The composition of imports reflects in turn, changing of the domestic production structure. Imports of capital goods (machinery,

4 "La concurrence pratiquée par les pays récemment industrialisés peut entraîner des pertes sur le marché de tel ou tel article; mais normalement, ces pertes tendent à être compensées par des gains résultant de la nouvelle demande que suscite, de différentes façons, la concurrence en question." Industrialisation et commerce extérieur, p. 145. 
technology, transportation) were in the beginning predominant $(38.3 \%$ in 1950); its share diminished until 1989 to only a quarter of total imports. Reducing the share of the first group was compensated by the increase of imports of fuels and raw materials utmost for the productive consumption (from less than a quarter of total imports in 1950, this group held more than half of Romania's imports in the period 1980-1989).

The evolution of the two groups of goods reflects the trade policy decisive orientation towards supplying the national economy with the means to accelerate the industry development. The two groups represented in 1989 over $80 \%$ of total imports. Overall, consumption of capital goods approached a share of $85-90 \%$ in 1990 .

Consumer goods intended for population consumption became less significant in imports, reaching only more than $15 \%$ of the total.

Corresponding to this evolution of the structure of imports, industrial products in all three processing phases (raw materials, semi-finished and finished products) mark a permanent increase, contributing at least three quarters of the total and a maximum of $85 \%$, the difference being represented by products of agricultural origin (raw materials and food).

\section{Foreign trade flows between 1950 and 1989}

In the period 1950-1989 the countries with which Romania has maintained foreign trade relations were grouped into two broad categories: socialist countries (mainly countries CMEA) and capitalist countries.

At the end of 40 years, according to data reported in 1989, Romania's foreign trade was distributed as follows:

- $60 \%$ of total trade was run with socialist countries $(52 \%$ with CMEA countries and $8 \%$ in other socialist countries);

- $40 \%$ of the total volume of foreign trade was run with capitalist countries, of which $25 \%$ of the developed capitalist countries and $15 \%$ in developing countries. [Constantinescu, 2000]

The evolution of geographic orientation or, better said the geoeconomic development of Romania's trade was not linear. If at the beginning of the $7^{\text {th }}$ decade almost three quarters of the foreign trade ran with socialist countries, after 1965 the trade with the West increased year after year, so that 

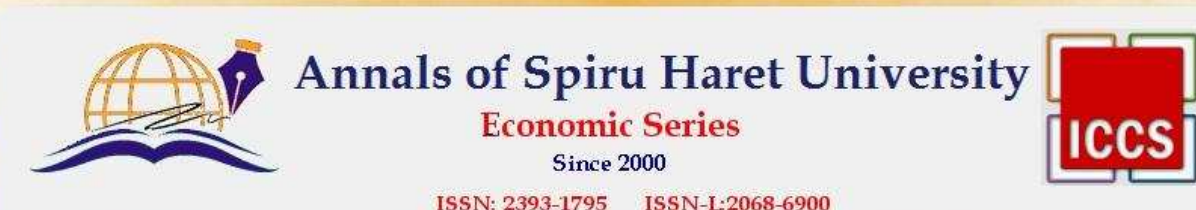

Issue 4/2015

between 1975 and 1980, the capitalist countries held between 55 and 59\% (of these, over a third were developed capitalist countries).

Significant is the pattern of the different categories of countries. The technology import was originally, respectively in the first decade, developed as a priority from the socialist countries (mainly the USSR); after 1965, the importance of imports of machinery, plant, equipment from the West grew significantly.

On the other hand, it is necessary to highlight the orientation of the exports of machinery and equipment in the decades 7,8 and 9 to the developing and least developed countries. It is not insignificant that after declaring Romania's foreign debt payment in 1989, Romania's outstanding debt to these countries amounted to $\$ 2$ billion. [Constantinescu, 2000]

Along with the effort to pay the external debt in the $9^{\text {th }}$ decade, the imports of consumer goods for the population declined from 11\% in 1970 to $7 \%$ in 1989. The domestic consumption situation was also aggravated by the growth of exports of increasingly diversified and high quality consumer goods.

\section{Conclusions}

The historical time for a possible reduction of disparities through industrialization was extremely short for Romania. Basically, given that in the $6^{\text {th }}$ decade (1951-1960) the economic growth recorded moderate rates, it's only 25 years, from 1964 to 1989, during which the accelerate pace of industrialization has reached the maximum. The increase in volume and the diversification of import and export structure reflected and enhanced the development of industry.

As a consequence of the socialist industrialization, production diversification and domestic supply of consumer goods, as well as the imports from both CMEA and the West markets have reshaped consumer habits and managed to stir up, to a large extent, the "lust" for consumption of the population.

Socialism had fulfilled its historic mission: domestic consumer demand structure became compatible with the supply structure of the major international industrial producers. In 1990 the West had a serious 
outlet in Romania, a country which has become in less than half a century a good potential customer for Western products manufacturing firms.

Most economic and sociological analysis on Romania's socialist industrialization stressed that most technologies imported during 1950-1980 were mainly energy-intensive, polluting and uncompetitive in relation to the dynamics of technological progress in developed countries. The analyses on the worsening gap between the level of industrial development in Romania and in European countries are flawed, however, by a dangerous bias, as if taken from the socialist ideology: the premise of the approach of Romanian economy growth is the continued growth at any cost!

Moreover, the myth of perpetual growth based on the permanent industrial revolution conquered the minds of economists and politicians since the nineteenth century. For the good of the peoples that had been isolated from the benefits of the "industrial production", the policy of artificial industrialization was considered a vital necessity since the second half of the nineteenth century. Promoted with maximum intensity during socialism, industrialization has radically changed the consumer habits, as well as the structure of actual and potential demand for food and non-food consumer goods.

In 1990 the structure of the Romanian economy corresponded to the standards of an industrial-agrarian economy. Consequently, the structure of consumer and most of investment demand had become compatible with the structure of the processed industrial products supply from developed countries.

The artificial growth in socialism has generated a series of negative reactions already anticipated by the study of the League of Nations in 1945, Industrialization and foreign trade. Still striking is the study's accurate prediction about the cancellation of the industrial development support when the international interests will require. ${ }^{5}$

By restricting imports, the policy of foreign debt forced payment applied in the period 1981-1989 had led to the abandonment of technology

5 "Toutefois, ce développement [industriel] exige généralement de lourds sacrifices dans le pays où il se produit et il s'avérera, en partie, antiéconomique lorsque les relations internationales normales seront rétablies", Industrialisation et commerce extérieur, Société des Nations, Genève, 1945, p. 142. 

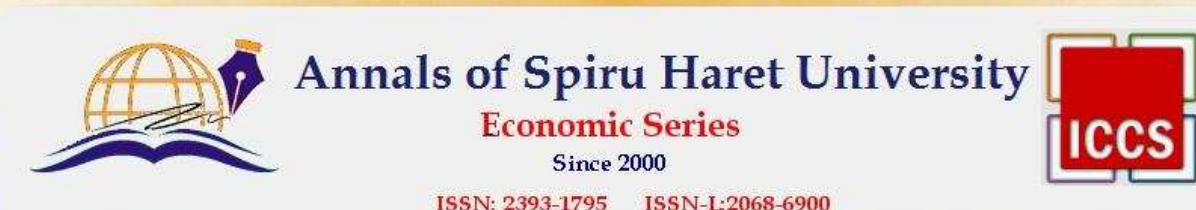

Issue 4/2015

transfer and modernization efforts undertaken in the previous decade (19711980). The partial sacrifice of domestic consumption and economic growth in favour of the forced payment of external debt was unable to totally compromise the chances of resuming growth after 1989.

The potential of the Romanian economy in 1990 was long called "the heavy legacy of Communism". Indeed, the accumulation of socialism decades has proved to be extremely difficult to manage after 1990. With very few exceptions, the "achievements of socialism" were wasted mostly in the first decade of transition.

However, without being advanced in the hierarchy of European countries, despite the structural imbalances "bequeathed" by the socialist regime, the industrial and agricultural potential of Romania in 1989 was considerable, constituting a starting stage of EU integration.

The end of socialism brought with it the hope that all the evils of the authoritarian leadership, more and more distant from the reality of the Romanian economy, would disappear. Many people dreamed then, in the early 90 s, the years that were to come were to summarize what was good in socialism with what was enshrined as good in capitalism.

Further development of domestic production, the composition of foreign trade and the position of foreign trade balance were influenced and determined by the European and international economic conjuncture, as well as by the interests of the new political elite to carry or not on the accelerated growth policy specific especially to the "Ceauşescu era".

Restructuring and harnessing the potential of the Romanian economy depended on the economic policy of governments during transition (namely pre-accession to the European Union). What they did with the "heavy legacy" will be presented in another article.

Here we must conclude that socialism was nothing but a historically necessary stage towards globalisation. Who regards globalisation as an unavoidable process should also praise the "socialism achievements"! This, at least, if we follow out J.A. Schumpeter, considering that "the subject matter of economics is essentially a unique process in history time." [Schumpeter, 1954] 


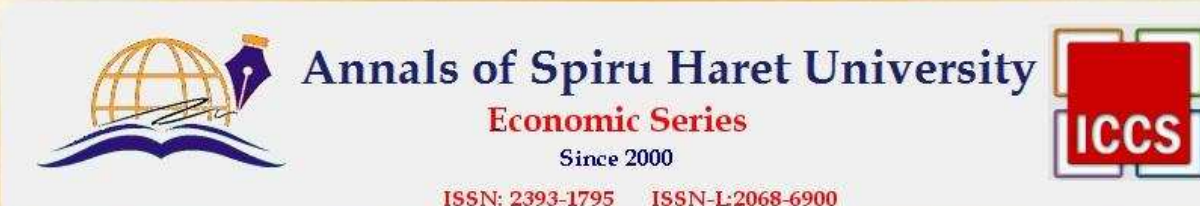

Issue 4/2015

References

*** Industrialisation et commerce extérieur, Société des Nations, Genève, 1945.

*** NBR Statistical Annual Report 1998.

*** Romanian Statistical Yearbook, 1990.

Bondrea, A., Starea naţiunii 2000. România încotro? (Bucureşti: Editura Fundaţiei România de Mâine, 2000).

Constantinescu, N.N., Istoria economică a României, vol. II (Bucureşti: Editura Economică, 2000).

Ghiorghiţă, E., Economic History. Lecture Notes (Bucureşti: Editura Fundaţiei România de Mâine, 2016).

Kiriţescu, Costin C., Sistemul bănesc al leului şi precursorii lui, vol. III (București: Editura Enciclopedică, 1997).

List, Friedrich, Das Nationale System der politischen Oekonomie (1841).

Manoilescu, M., Forţele naţionale productive şi comerţul exterior. Teoria protecţionismului şi a schimbului internaţional (Bucureşti: Editura Ştiinţifică şi Enciclopedică, 1986).

Schumpeter, J.A., History of Economic Analysis (Allen \& Unwin Ltd, 1954). 
